UK plutonium worries US Senate

\section{Alarm at link between civil and bomb uses}

\section{Washington}

US senators may soon start investigating the fate of as much as four tons of fuelgrade plutonium that the United Kingdom supplied to the United States over several years on the understanding that it would be used only for civilian purposes, but which may have been put into nuclear warheads by US authorities. The plutonium originated in the Magnox reactors of the Central Electricity Generating Board.

Last October the two governments apparently agreed that the United Kingdom would resume providing plutonium to the US Department of Energy (DoE) to help indirectly with the DoE's programme for producing and modernizing US nuclear warheads.

Under a previous barter agreement that ran from 1964 to 1971 , the United States supplied the United Kingdom with highly enriched uranium for its nuclear submarine programme and with tritium for UK nuclear weapons. In return, the United Kingdom supplied an unspecified amount of plutonium from Magnox reactors. The terms of the accord have always been secret, but in 1964 a British government spokesman indicated that the United States had no intention of using the plutonium thus obtained for nuclear weapons. Now, however, Senators Gary W. Hart (Democrat, Colorado), Alan K. Simpson (Republican, Wyoming) and George J. Mitchell (Democrat, Maine) seem likely to act on a request from a public interest group that they look into how much plutonium was shipped to the United States between 1964 and 1971 .

The Senate investigation reflects a growing concern in the United States about DoE's plans to link civilian and military nuclear programmes, a move away from the historic separation between "atoms for peace" and "atoms for war". Recently, DoE has announced that there is a "shortage" of plutonium (DoE designs and builds nuclear weapons for the Department of Defense). So it plans to take plutonium from spent fuel from several civil research reactors to fashion more weapons grade material.

DoE also wants to convert the 17.8 tonne stockpile of fuel-grade plutonium now destined for the breeder reactor at Clinch River, Tennessee, for weapons use. This stockpile may well include much or all of the plutonium supplied under the barter agreement. "Either it is in the US nuclear weapons already, or it is in the stockpile

meant to fuel the breeder, but now destined for weapons,"' says S. Jacob Scherr, senior staff attorney for the Natural Resources Defense Council Inc.

According to the Natural Resources Defense Council, existing US nuclear weapons utilize about 90 tonnes of plutonium (plus or minus 15 tonnes). Current weapons-grade plutonium production by DoE has run about 1.4 tonnes per year, but DoE wants to step this up to 2 to 3.5 tonnes annually. In October, the UK government allegedly agreed to send more plutonium to the United States. The British plutonium may be going to fuel the breeder at Clinch River so that fuel otherwise destined for the breeder can be diverted into nuclear weapons. John Moore, Parliamentary Under-Secretary of State at the UK Department of Energy, was questioned about the plan in March.

DoE seems likely to continue to press the United Kingdom for more plutonium, because Senators Hart, Simpson and Mitchell have succeeded in cutting off another possible source - by a vote of 88 to 9 , on 30 March, the Senate voted for an amendment to prohibit DoE from using spent fuel from commercial reactors for its nuclear weapons programme. In a debate in the House of Commons on 21 December 1981, Mr Moore emphasized that civil plutonian sold to the United States would be subject to international safeguards, but he implied that military plutonium transferred under the defence agreement would not be so restricted.

\title{
Oak Ridge up for grabs
}

\section{Washington}

On 3 May, the Union Carbide Corporation, which has run government atomic facilities at Oak Ridge, Tennessee, since the Second World War, announced that it no longer wants to do so. Union Carbide is not seeking to renew its option to manage Oak Ridge when the present contract expires on 30 September 1983. Recognizing the dislocation that its decision could cause, however, the company says it will stay on for up to three years longer if necessary.

The names Oak Ridge and Union Carbide have been almost synonymous in government science circles and in the Tennessee Valley region since the first gaseous diffusion plant was built there, amid great secrecy, during the Second World War. At that time, the company was heavily involved in manufacturing carbon products, but has since grown (its 1981 sales were $\$ 10,000$ million) and diversified into batteries, antifreeze, car care products, even salmon farming and ferroalloys. But earnings have been down of late, and the company has been divesting itself of activities which are not central to

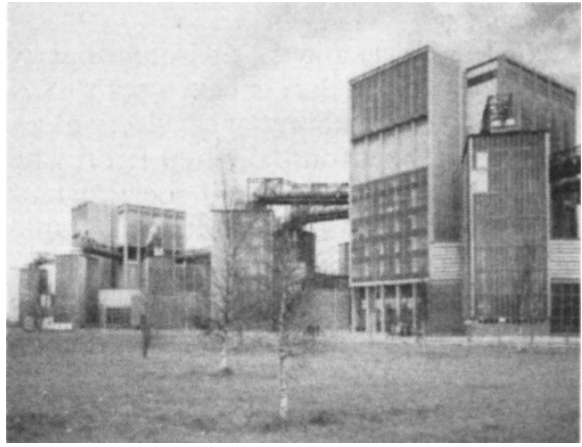

The Magnox at Berkeley in Gloucestershire - source for US bombs?

DoE has also decided to proceed with the Laser Isotope Separation facility at Lawrence Livermore Laboratory, which would cost an estimated $\$ 560$ million and which the Natural Resources Defense Council claims has no justification other than to enrich plutonium from civil reactors to weapons-grade material. DoE also seeks to build a decladding plant to utilize fuel from noncommercial plants, such as the Fast Flux Test Facility at Hanford, Washington.

The issue at stake is not only the historic separation between civilian and military nuclear programmes, but also the precedent that DoE is setting for other countries. Critics of DoE's plans argue that if the United States starts taking civilian spent fuel from its weapons programme, it will not have a leg to stand on when it tries to dissuade other countries from doing likewise.

Deborah Shapley its purpose. So it is shedding Oak Ridge.

Union Carbide is one of the most respected corporate managers of any government laboratory in the nation. It actually runs four facilities - Oak Ridge National Laboratory, the Oak Ridge gaseous diffusion plant, the Oak Ridge Y-12 plant that makes nuclear weapons components, and the gaseous diffusion plant in Paducah, Kentucky. Union Carbide's act will be hard to follow.

The government spends about $\$ 1,000$ million a year on these facilities, paid through the company, which has 18,000 employees working there on its payroll. Its fee for the operation is $\$ 8$ million per year, from which come some expenses. The Department of Energy, which holds the contract with Union Carbide, may decide to open four separate bids, one for each of the facilities, rather than ask a single company to follow in Union Carbide's footsteps. As a side effect, this might hasten changes in the mission and role of the Oak Ridge laboratory itself, which is under White House review, along with the other departmental laboratories.

Deborah Shapley 